\title{
Shortage of Teachers and Recruitment of Technology Teachers at the University in Eastern Cape Province, South Africa
}

\author{
Moses Makgato and Sammy Khoza
}

\begin{abstract}
Shortage of teachers, particularly technology teachers is of great concern in the country. In order to increase the supply side the department of education has expanded funding for student teachers who pursue technology Teacher Programme and other scarce skills. The universities should increase the recruitment strategies to students in the TTE programme. The purpose of this study was to identify effective recruitment techniques that attract students to the technology education teaching profession. Convenience and purposive sampling method was used to obtain 30 new TTE students to participate in the study. Questionnaire and interviews were used to collect data. From the findings, it is clear that financial injection is the main pillar to attract student teachers into the TTE program in the Eastern Cape University. It is recommended that the Eastern Cape Province University intensify recruitment strategy to attract students into the TTE program because funding is available so that technology teachers are increased throughout the province and the country.
\end{abstract}

Index Terms-Shortage, technology teacher programme, Eastern Cape university.

\section{INTRODUCTION}

Identifying and recruiting prospective technology students teachers has been an ongoing concern for more than two decades world wide [1]. Considerable research was conducted during the late 1970s and early 1980s relative to teacher recruitment [2]. These studies were prompted by declining enrollments in university programs and reported shortages of industrial arts teachers in forty-one states [3]. In some cases, this shortage of technology teachers led to high school programs being closed or cut back, the utilization of under-qualified personnel, and the abandonment of planned expansion [2]. This was the case with South Africa whereby new technology subjects at schools required teachers desperately, especially at rural school.

\section{A. The Demand for Technology Teachers at Schools}

In many countries, world wide, technology education is a new subject under development at schools [4], [5]. This has, and continues to be the case in developing countries such as South Africa with the development of Curriculum 2005 and its implementation in 1997. There are other countries that have developed and implemented technology education, for example, in 1992 Botswana developed a national curriculum policy in which Design and Technology (Technology)

Manuscript received November 14, 2012; revised July 10, 2013.

The authors are with the Tshwane University of Technology, Gauteng Province, South Africa (e-mail: MakgatoM@tut.ac.za). became one of the eight core subjects [6]. In 1990, England introduced Design and Technology into schools [7]. The quality of technology education programmes is greatly determined by the teachers with knowledge and skills required to teach learners.

There is shortage of teachers, especially technology subject teachers worldwide, and is predicted that it will continue to increase [8]. Education scholars in South Africa also concur that there are shortages of teachers in schools [9]. The relatively low number of Black students studying teacher education in the 25 year -and under is caused by the fact that majority of them come from disadvantaged schools and poor socio-economic environment. The skills shortage in SA is directly related to the quality and quantity of education provided to the majority of South Africans, especially in the past. The shortage reflects the type of education that was made available to the majority; the exclusivity of quality education for a few; and the general lack of access to education for many.

While data point to the fact that there is no shortage of teachers, there are however challenges in terms of the supply of teachers available. The challenges include a reported mismatch between demand and supply of teachers. These are some of the challenges:

1) There are few qualified teachers in technology subjects.

2) There are more Humanities and Social Science teachers than technology teachers, which results in a great demand for the latter teachers, while there is an oversupply of the former.

3) More teachers prefer urban areas to rural areas.

Most teachers in the classrooms were trained for the previous dispensation classrooms (apartheid education, the discredited and discarded curricula, and homogeneous classrooms). It will take time before the new cadres of teachers, who are supposedly well-trained, and prepared for today's classrooms, make an impact in the classrooms, and to positively change the education system. However, there are several continous professional programme that address the past practices in teacher education. The number of teachers who leave the profession is not matched by the number of incoming teachers (just qualified and immigrants) - the scale heavier on the side of the former [10]. Urban schools do not experience shortage of qualified and skilled teachers as rural areas do. Former white schools do not experience a shortage of qualified and skilled teachers as black schools do. Fewer black students register at university to do teacher education than white students. This leads to the black race, and therefore, black schools and black areas having a shortage of qualified and specialised teachers [8], [10]. The bursary scheme, "Fundza Lushaka" introduced at the end of 2006 for 
2007, offering bursaries to students who want to register for teacher education at university, did not attract as many students as needed.

\section{B. Response to Teacher Shortage and Rectruitment of Teachers}

Increasing the supply depends on significantly increasing the number of new entrants to initial teacher education, improving the success rate, encouraging more newly qualified teachers to teach and successfully maintaining the recruitment pressure year after year. The Department is committed to investing resources in the initial education of teachers through an expanded programme of funding for student teachers, who, once qualified, will enter into service contracts with provincial education departments [11]. The programme will be coupled with a strong, responsible and appropriately-pitched marketing campaign to raise the visibility, attraction and challenge of teaching as a career for the best and brightest of our young people across the land, among all communities, in urban and rural areas. This study was conducted to determine the extent to which teachers of technology are recruited in order to address the shortage.

\section{Purpose of the Study and Research Questions}

The purpose of this study was to identify effective recruitment techniques that attract students to the technology education teaching profession. The following research questions guided the study:

1) What are the effective recruitment techniques and influential factors used by Eastern Cape university to attract students for TTE?

2) What attracted students in choosing TTE and who influenced them in their career choice?

\section{Methodology AND ReSUlts}

\section{A. Research Sample and Instrument}

Convenience and purposive sampling method was used to obtain 30 new TTE students to participate in the study. Data collection was done by means of interviews with teachers and the completion of questionnaires. According to [12], the purpose of interviews is to obtain in-depth information and the quality around a particular activity. Therefore data was collected from thirty (30) new TE students, that is, ten (10) doing civil technology, 10 from Electrical technology and the other 10 in Mechanical technology. The questionnaire data was analyzed using statistical frequency technique of SPSS, while interview data was analysed using coding and thematic technique.

None of the thirty students come from urban schools; they are all from rural and deep rural technical schools (where schools are under-resourced and or overcrowded).

\section{B. Questionnaire Data Responses}

The Table I above shows students responses when about the type of recruitment that made them to study technology teacher education (TTE) programme. Majority (47\%) of students said that they informed by the current student teachers about the demand to study TTE programme. Almost quarter $(23 \%)$ of students said that they were recruited to study TTE programee by university marketing officer who came to their school.

TABLE I: RECRUITMENT STRATEGIES OF STUDENTS TO STUDY TECHNOLOGY TEACHER EDUCATION

\begin{tabular}{|l|l|l|}
\hline Recruitment technique & \multicolumn{2}{|l|}{ Student's response } \\
\hline & $\mathbf{N = 3 0}$ & $\mathbf{\%}$ \\
\hline None & 3 & 10 \\
\hline Univ. Recruiter to HS & 14 & 23 \\
\hline Brochures & 1 & 3 \\
\hline Face-to-Face Interactions & 3 & 10 \\
\hline Alumni & 2 & 7 \\
\hline Current TE Students & 7 & 47 \\
\hline TOTALS & $\mathbf{3 0}$ & $\mathbf{1 0 0}$ \\
\hline
\end{tabular}

\section{Interviews Data Responses}

\section{The main reason in choosing the TE program}

Students were interviewed in order to obtain in-depth information about how they came to study TTE programme. Most $(53 \%)$ of the $1^{\text {st }}$ year students said that they applied through their respective District education departments which put them in the TE program of the university so that they can be funded by the provincial education department; while some said they chose the programme because of financial support as compared to other programs.

One male student was recorded as saying "for the fact that I have applied via my District office in Lusikisiki, which is in the Eastern Pondoland, even accommodation is guaranteed". On the other hand his other male counterpart also said the following: "at my District in Butterworth, I was also guaranteed that I will be placed in the nearby Bread and Breakfast (BnB) accommodation for the duration of my studies"

However, $20 \%$ of the female students said since they are parents already, they have the opportunity to utilize their child's support grant specifically for their kids because tuition is sponsored by either a students' loan, bursary or learner-ship provincial schemes.

A female student responded by saying: "I just love the fact that if you are not successful in securing yourself a National Student Financial Assistance Scheme (NSFAS) loan, I can still apply on line for a Funza Lushaka bursary that is specifically reserved for education courses". On the other hand her female classmate said: "I have a child and my mom already has a problem in paying for my tuition, so the TTE program is funded a lot by the Provincial and National funders who leave me with a child support grant to take care of my son".

\section{DISCUSSIONS}

From the questionnaires' results it is evident that students were not necessarily been recruited by the university in enrolling for the TE program but their technology teachers at schools did. This is also supported by the writing of [1] as outlined earlier on that recruiting technology teachers has been a concern for many decades. This concern can only be addressed by HEI's because they are the ones offering programs. It is also clear that the university does not have brochures or do not rely on brochures in recruiting secondary school learners into the TE but most of the information about the TE program is found from returning students who in turn tell the new ones. This might also be the reason why the 
teacher education in SA is under such a considerable flux as outlined in this study [13]. Perhaps if brochures and other relevant instruments were put in place, the number of first year intake in the Eastern Cape Province University would double.

The interviews revealed that financial support is the main drive of students in enrolling into the TE program in the university. This is further supported by [14] that the Eastern Cape Province is one of the poorest Provinces where access to schooling is a challenge. That is why students opt for easier pathways in studying by enrolling in the TE program which is greatly funded. Even though a few of female students revealed that they are parents, having tuition fees being taken care of will ease their worries of child maintenance back home. However what [15] said that in the Western Cape alone the number of teachers in the HEI's has declined is not really the case in the Eastern Cape Province as the TE program is stable, ranging from 50- 60 students per year.

\section{CONCLUSION}

From the findings, it is clear that financial injection is the main pillar of the TTE program in the Eastern Cape University. The enrolment figures are fairly stable on 50- 60 new students per year rely because of availability of loans, bursaries and or learner-ship funding. It also was revealed that most of the students did not pass their Grade 12 and immediately went to tertiary but they stayed at home for a year or two because of financial difficulty. This is surprising in that majority of students come from poor socio-economic environment. It will therefore be wise for the Eastern Cape Province University increase the number of intake into the TTE program because funding is available so that technology teachers are increased throughout the province and the country.

\section{REFERENCES}

[1] M. D. Wright and L. R. Custer, "Why they want to teach: Factors influencing students to become technology education teachers," Journal of Technology Education, vol. 10, no. 1, pp. 58-70, 1998.

[2] D. H. Devier, "The recruitment of industrial arts teacher education students in Ohio," Journal of Industrial Teacher Education, vol. 19 no. 3, pp 27-38, 1982 .

[3] M. D. Wright, "Relationships among esteem, autonomy, job satisfaction and the intention to quit teaching of downstate Illinois industrial education teachers," Doctoral Dissertation, University of Illinois, Dissertation Abstracts International, vol. 46, pp. 32-73, 1985.

[4] R. Kimbell, K. Stables, and R. Green, "The nature and purpose of Design and Technology," in Teaching Design and Technology in Secondary Schools, G. O. Jackson, Ed. England: Open University Press, 2002, ch. 2, pp. 19-30.

[5] R. C. Wicklein, "Developing goals and objectives for a process-based technology education curriculum," Journal of Industrial Teacher Education, vol. 30, no. 3, pp. 66-80, 1993.

[6] O. B. Molwane, "Assessing technology education in botswana junior secondary curriculum: Case study of teachers' classroom practices," in Proc. the Design and Technology International Millennium Conference, Wellesbourne: The D \& T Association, 2000, pp. 121 $-127$.

[7] R. Cormick, "The coming of technology education in England and Wales," in Teaching Design and Technology in Secondary Schools, G. O. Jackson, Ed. England: Open University Press, 2002, ch. 3, pp. 31-47.

[8] H. B. Ndahi and J. M. Ritz, "The Technology teacher education demand and supply," The Technology Teacher, vol. 62, no. 7, pp 27-31, 2003.

[9] F. Arends, "Teacher shortages? The need for more reliable information at school level," Review of Education, Skills Development and Innovation: HSRC, Pretoria, 2011, pp. 1-10.

[10] T. Mda and J. Erasmus, "Scarce \& critical skills-Educators," Research Commissioned by Department of Labour in South Africa, Pretoria: Government printers, March 2008, pp. 1-60.

[11] Department of Basic Education, Information guided on Initial Teacher Education - Becoming a Teacher, Government Printers: Pretoria, 2012, pp. 1-28.

[12] M. Makgato, "Identifying constructivist methodologies and pedagogic content knowledge in the teaching and learning of technology," Procedia-Social and Behavioral Sciences, vol. 47, pp. 1398-1402, 2012.

[13] South African Council of Educators (SACE), "A review of teacher demand and supply," Identifying Research Gaps and the Role of SACE. Pretoria: Government Printers, July 2010, pp. 1-29.

[14] N. Tailor, "Equity, efficiency and the development of south African schools," in International Handbook of School Effectiveness and Improvement, T. Townsend, Ed. Dordrecht: Springer, 2007, vol. 17, pp. 523-540.

[15] P. Vinjevold. (20 October 2004). Quoted by Business Day, 29 $\begin{array}{lll}\text { September } & 2002 . & \text { [Online]. }\end{array}$ http://www.bday.co.za/bday/content/direct/1\%2C3523\%2C1095576-6 096- $0 \% 2 \mathrm{C00}$

Moses Makgato is an associate professor at Tswane University of Technology in South Africa, Gauteng Province. Prof. Makgato is teaching Technology to students teachers in the Technology teacher education programme. He supervises postgraduate students in masters and doctorate programmes in the area of Technology and Educational Technology.

Sammy Khoza is a lecturer at Wits University, school of education in South Africa. Dr. Khoza is teaching Technology to students teachers in B.Ed programme of Technology Education. He co-supervises masters and doctorate programmes in the area of Technology and Technical and Vocational Education. 